ЧАСТОТА ГЕПАТОТОКСИЧЕСКИХ РЕАКЦИЙ У ВПЕРВЫЕ ВЫЯВЛЕННЫХ БОЛЬНЫХ ТУБЕРКУЛЕЗОМ ЛЕГКИХ С ГЕНЕТИЧЕСКИМ ПОЛИМОРФИЗМОМ ГЕНОВ-ФЕРМЕНТОВ, ОТВЕТСТВЕННЫХ ЗА БИОТРАНСФОРМАЦИЮ КСЕНОБИОТИКОВ

\author{
Казаков А. В., Можокина Г. Н., Клевно Н. И., Смердин С. В., Пахлавонова А. Д., Сенчихин П. В., Дадашева Х. Б. \\ ФГБУ «Национальный медицинский исследовательский центр фтизиопульмонологии и инфекционных заболеваний» \\ МЗ РФ, Москва, РФ

\section{FREQUENCY OF HEPATOTOXIC REACTIONS IN NEW PULMONARY TUBERCULOSIS PATIENTS WITH GENETIC POLYMORPHISM OF GENE-ENZYMES RESPONSIBLE FOR XENOBIOTIC BIOTRANSFORMATION}

\author{
Kazakov A. V., Mozhokina G. N., Klevno N. I., Smerdin S. V., Pakhlavonova A. D., Senchikhin P. V., Dadasheva Kh. B.
}

National Medical Research Center of Phthisiopulmonology and Infectious Diseases, Moscow, Russia

Одной из причин недостаточно высокой эффективности лечения больных туберкулезом является отсутствие возможности соблюдения оптимальных (стандартных) режимов лечения в силу высокой частоты нежелательных реакций на противотуберкулезные препараты (ПТП). В настоящее время клинические рекомендации по назначению режимов приема ПТП содержат усредненные параметры фармакокинетики препаратов, что не обеспечивает максимальной эффективности лечения. Наиболее часто при назначении лечения впервые выявленным пациентам с туберкулезом органов дыхания наблюдаются гепатотоксические реакции (ГТР) на ПТП, особенно на рифампицин.

Цель исследования: повысить эффективность и безопасность химиотерапии у больных туберкулезом, используя генотипические характеристики пациента, полученные при молекулярно-генетических методах исследования.

Материалы и методы. В исследовании приняли участие 78 человек ( 38 мужчин и 40 женщин). 50 пациентов в возрасте $25-65$ лет и 28 детей и подростков в возрасте 5-16 лет. Больным в схеме химиотерапии назначали изониазид, рифампицин и пиразинамид. ГТР регистрировали при наличии клинических проявлений (тошнота, рвота) и/или изменении уровня АлАТ и АсАТ более чем на 2 нормальных интервала. Такие реакции наблюдались у 23/78 (29,5\%) пациентов: во взрослой группе - у 17/50 (34,0\%), у детей и подростков $-6 / 28(21,4 \%)$.

Статистически значимой разницы в частоте проявления ГТР между возрастными и гендерными категориями пациентов не выявлено. $14 / 23$ (60,8\%) больных имели ГТР в виде повышения АЛТ и АСТ, а $9 / 23(38,2 \%)$ пациентов - в дополнение к этому и клинические проявления.

При развитии ГТР гепатопротективную терапию назначали всем пациентам.
Для проведения лабораторных исследований брали цельную кровь, проводились выделение геномной ДНК пациента и постановка полимеразной цепной реакции в режиме реального времени.

У включенных в исследование пациентов в качестве возможных предикторов развития ГТР рассматривалось наличие генотипов, относящихся к генам: rs1801279, rs1799931, rs1799930, rs1799929, rs1801280, rs1208, rs1041983, rs1045642, rs74837985.

Для прогнозирования развития гепатотоксичности при применении ПТП в зависимости от наличия или отсутствия в геноме пациента определенных генотипов использовался метод логистического регрессионного анализа. Проводилось построение моделей логистической регрессии с поочередным включением каждого предиктора. Построение логистической регрессионной модели осуществляли методом пошагового включения прогностических факторов с оценкой коэффициента детерминации $\mathrm{R} 2$, показывающего долю влияния каждого из предикторов модели на дисперсию зависимой переменной. Проверка статистической значимости модели осуществлялась при помощи критерия $\chi^{2}$. При значении $p<0,05$ гипотеза о незначимости модели отвергалась. Чувствительность и специфичность предикторов оценивали при помощи ROC-анализа. Количественную интерпретацию результатов проводили по ROC-кривым с оценкой показателя AUC (Area under ROC curve - площадь под ROC-кривой).

Результаты. У большинства 15/23 (65,2\%) пациентов ГТР носили обратимый характер, однако у $8 / 23$ (34,8\%) из них потребовалась отмена рифампицина.

При проведении логистического регрессионного анализа получены 2 статистически значимые модели. Первая модель отражает ассоциированность генотипа АА гена rs1799931 и генотипов AA и AG (аллеля A) гена rs1799930 с 
проявлениями гепатотоксичности ПТП, коэффициент детерминации $\mathrm{R} 2=0,144, \mathrm{AUC}=0,685 \pm 0,064$ (95\%-ный ДИ 0,560-0,811), $p=0,008$. Вторая модель отражает связь проявления гепатотоксичности ПТП с генотипами ТТ и СТ (аллеля Т) гена rs1041983, $\mathrm{R} 2=0,109, \mathrm{AUC}=0,655 \pm 0,063$ (95\%-ный ДИ 0,532-0,779), $p=0,026$.

Заключение. ГТР у впервые выявленных пациентов с туберкулезом органов дыхания чаще всего развиваются на рифампицин и носят обратимый характер. Наличие генотипа АА гена rs1799931 и генотипов АA и AG (аллеля А) гена rs1799930, а также присутствие генотипов ТТ или СТ (аллеля Т) гена $r s$ 1041983, определяющие активность фермента NAT2, статистически значимо увеличивают риск развития ГТР при приеме ПТП у больных туберкулезом легких.

Казаков Алексей Владимирович

(Aleksey V. Kazakov)

E-mail: alexeykazakov1982@yandex.ru

\section{НОВЫЙ ВЕКТОР В ПРЕПОДАВАНИИ ФТИЗИАТРИИ СТУДЕНТАМ-ПЕДИАТРАМ}

Лозовская М. Э., Васильева Е. Б., Клочкова Л. В., Яровая Ю. А., Степанов Г. А.

ФГБОУ ВО «Санкт-Петербургский государственный педиатрический медицинский университет» МЗ РФ, Санкт-Петербург, РФ

\section{A NEW VECTOR IN TEACHING PHTHISIOLOGY TO PEDIATRICIAN STUDENTS}

Lozovskaya M. E., Vasilieva E. B., Klochkova L. V., Yarovaya Yu. A., Stepanov G. A.

St. Petersburg State Pediatric Medical University, St. Petersburg, Russia

Цель исследования: провести анализ новых методов интерактивного преподавания дисциплины «фтизиатрия» студентам, обучающимся по специальности «педиатрия» во ФГБОУ ВО «СПб ГПМУ» Минздрава России; разработать рекомендации по применению наиболее востребованных из них.

Материалы и методы. Проанализированы методы и технологии, применяемые в преподавании фтизиатрии на кафедре фтизиатрии СПб ГПМУ на протяжении последних трех лет (2016-2018 гг.) с использованием интерактивного подхода. Изучены динамика успеваемости студентов и результаты их анкетирования, определен рейтинг тематических занятий.

Результаты. В течение последнего десятилетия происходит модернизация российского высшего образования, которая заключается в переходе от учебно-образовательного к научно-образовательному процессу и подразумевает не усвоение студентами готовых знаний, а овладение методами познания. При этом основной задачей становится формирование у студентов самостоятельности и творческой активности, что требует применения методов и технологий обучения, адекватных компетентностному подходу к подготовке специалистов. Именно компетентностный подход является механизмом приведения педиатрического образования в соответствие с требованиями современности. С целью развития у студентов общекультурных, общепрофессиональных и профессиональных компетенций на кафедре фтизиатрии СПб ГПМУ применяются следующие методы активного обучения: учебно-исследовательская работа студентов, научно-исследовательская работа студентов, проблемное обучение (проблемные семинары, лекции, семинары, дискуссии, мозговой штурм), интерактивные лекции, ролевые игры, игровые педагогические упражнения. Последние включают несколько видов технологий, в 2016-2018 гг. внедрены упражнения «алгоритм», «глоссарий» и др.

Обращение к методу «алгоритм» связано с необходимостью овладения будущими врачами-педиатрами основными нормативными документами, регламентирующими их деятельность по туберкулезу. Это важно при работе в медицинских организациях различного уровня, особенно на уровне первичной врачебной медико-санитарной помощи. Медицинский алгоритм в клинической медицине - пошаговый протокол для решения задач врачебной практики, в настоящее время вытекающий из приказов, санитарных правил и федеральных клинических рекомендаций. Для того чтобы сделать самостоятельную работу студентов по овладению этой медицинской информацией творческой, увлекательной и современной, предлагаем им составление графических алгоритмов (блок-схем) с использованием компьютерной программы «Дракон-конструктор». Алгоритмический язык ДРАКОН (Дружелюбный Русский Алгоритмический язык, Который Обеспечивает Наглядность) используется в технике, биологии, медицине и образовании. Преимуществом 